\title{
Morphology, ecophysiology and germination of seeds of the Neotropical tree Alibertia patinoi (Rubiaceae)
}

\author{
Diego Fernando Escobar Escobar ${ }^{1} \&$ Alba Marina Torres G. ${ }^{2}$ \\ 1. Departamento de Biología, Universidad del Valle, Ciudad Universitaria Meléndez, A.A. 25360, Cali, Colombia; \\ barescoesco@gmail.com \\ 2. Departamento de Biología, Universidad del Valle, Ciudad Universitaria Meléndez, A.A. 25360, Cali, Colombia; \\ alba.torres@correounivalle.edu.co
}

\author{
Received 16-IV-2012. Corrected 05-IX-2012. Accepted 03-X-2012.
}

\begin{abstract}
Morfología, ecofisiología y germinación de semillas del árbol neotropical Alibertia patinoi (Rubiaceae). Alibertia patinoi (Rubiaceae) is of economic and cultural importance for communities in the Colombian Pacific and Amazon regions, where it is cultivated and mature fruits are highly appreciated and consumed. Since there is a lack of knowledge of the seed physiology of this species, we describe here the germination behavior and morphometry of seeds of Alibertia patinoi, and relate them to its habitat. Fruits were collected from a mixed food crop and a commercial plantation in Guaimía village, Buenaventura, Colombia, a tropical rain forest area. We measured length, width, thickness, mass ( $\mathrm{n}=1400)$, and moisture content of seeds $(\mathrm{n}=252)$. Primary dormancy tests were conducted $(n=200)$, followed by imbibition $(n=252)$ and germination dynamics, under different conditions of light and temperature specific to understory and forest clearings ( $\mathrm{n}=300$ seeds). Finally, seed storage behavior was established ( $\mathrm{n}=100$ seeds). We observed that size and mass of seeds had a narrow range of values that did not differ within or among fruits and that the species did not exhibit primary dormancy. The seeds are recalcitrant, and recently harvested seeds exhibited higher seed moisture content ( $c a$. $44 \%$ ) and continuous metabolism. The seed germination percentage was observed to be higher under the specific dense canopy forest light and temperature conditions; furthermore, neither enriched far-red light nor darkness conditions inhibited germination. We concluded that rapid germination could be the establishment strategy of this species. Also, the physiological traits (i.e., rapid germination rate, low germination requirements, absence of primary dormancy, and recalcitrant behavior) and seed size and mass, suggest that A. patinoi is adapted to conditions of mature tropical rain forests. Rev. Biol. Trop. 61 (2): 547-556. Epub 2013 June 01.
\end{abstract}

Key words: climax species, far-red light, mature tropical rain forest, non-pioneer species, non-dormant seeds, rapid germination strategy, recalcitrant seeds.

Seed biology constitutes a key element in clarifying the distribution and abundance patterns of species, and seed ecologists seek to understand how seed characteristics affect dispersal, colonization, and establishment of seedlings, and ultimately succession and natural regeneration of species (Dalling 2002, Vázquez-Yánez \& Orozco-Segovia 1993). Information on the physiology and ecology of seeds from the tropical rainforest is limited and is focused on pioneer species (VázquezYánez \& Orozco-Segovia 1993). Scarcer still are comprehensive studies of the germination behavior of a non-pioneer species, that is, germination requirements, kind of dormancy, seed imbibition, response to storage, and germination dynamics (Baskin \& Baskin 1998).

The establishment and survival of plant species in the rain forest are better known than germination and they vary with light condition (Paz et al. 1999). Seed morphology and shade tolerance seem to organize the community of seedlings and saplings. In general, recruitment of both small and large-seeded species is more frequent in lighter parts of the understory than in shaded understory (Svenning 2000). 
However, in the closed-canopied rain forest the establishment of large-seeded species is favored, and seedlings of about half of the seed species come from fruits produced in the forest, and half from fruiting trees from outside the forest (Martínez-Ramos \& Soto-Castro 1993). Large seeds are slowly removed by mammals from their sites (Paine \& Beck 2007), their germination is not regulated by light in understory conditions (Souza \&Valio 2001), and the seedlings grow slowly (Poorter \& Rose 2005). Successful establishment depends on external ecological effects, such as seedling establishment rate and spatial variation, animal interference, pathogens and litter accumulation, more than on seed mass itself (Paz et al. 1999, Svenning \& Wright 2005). For instance, a low ratio between red (R) and far-red light (FR) occurs in understory and determines germination and establishment of plants in the canopied forest (Orozco-Segovia et al. 1993).

Although the abiotic conditions of the tropical rainforest are highly variable, there are two groups of environmental conditions defined by the vegetation. A first group is found in open areas and forest clearings, where the temperature fluctuates widely and the amount of radiant energy from the sun is high and has a high ratio of red/far red. The other group is found on the floor of dense canopy forests, in conditions where light quality and quantity, and temperature fluctuations are low (Swaine \& Whitmore 1988).

According to the shade tolerance of seeds and seedlings, species can be classified as non-pioneer or pioneer. Following Swaine \& Whitmore (1988), seeds of pioneer species can only germinate in forest clearings or open areas, where the sunlight reaches the ground at least in part of the day. While in non-pioneer species, seeds can germinate in the shade of the forest, and the seedlings can establish and survive under the shadow of the forest (Swaine $\&$ Whitmore 1988). Although non-pioneer species can grow in forest clearings and under the dense canopy, they are more efficient in the latter site (Baskin \& Baskin 1998).
Rubiaceae is one of the plant families in the Neotropics with the greatest number of species (Mendoza et al. 2004). In Colombia it is one of the most diverse and abundant families in the Andean region, not the least in the rain forests of the Amazonian and Chocó biogeographic regions (Mendoza et al. 2004). Alibertia patinoi (Cuatrec.) Delprete \& C. Persson is a Rubiaceae of economic and cultural importance for communities in the Colombian Pacific and Amazon regions where this is cultivated and mature fruits are consumed in juices (Patiño 2002). According to this author, it is a dioecious species, propagated by seeds, domesticated long ago and apparently without wild populations. Currently, there is a lack of knowledge on the physiology of A. patinoi seeds, and this study aimed to investigate and describe the physiological and morphological traits of the seeds of $A$. patinoi and to relate them to its habitat.

\section{MATERIALS AND METHODS}

Collection site: The fruits were collected from a mixed plantation of about 2 ha in the village of Guaimía (343'6.97' N - 7657'47.11" $\mathrm{W})$, located in the Western part of the municipality of Buenaventura, Colombia. This area corresponds to the Anchicayá river basin and is classified as a tropical rain forest according to the system of Holdridge (Espinal \& Montenegro 1963). This is one of the wettest areas on Earth, being influenced by the proximity to the sea, with a high relative humidity (between 83 and 92\%), mean annual rainfall of about $6200 \mathrm{~mm}, 290$ days of rain a year and high soil water excess throughout the year, and nearly constant mean temperature of $26^{\circ} \mathrm{C}$, with extremes between 22.5 and $29.5^{\circ} \mathrm{C}$ (IDEAM 2001).

\section{Reproductive phenology and geograph-} ic distribution: To establish the distribution of the species and the reproductive phenology, we consulted the data bases of the herbaria of the Missouri Botanical Garden (MO), Universidad del Valle (CUVC), Universidad del Chocó 
(CHOCO), Herbario Nacional Colombiano (COL), and the Colombian Instituto Amazónico de Investigaciones Científicas (COAH), (THIERS 2012).

Seed morphometrics: We collected and weighed 10 ripe fruits using a Mettler Toledo PL1501S scale. The seeds from each fruit were disinfected with $2 \%$ sodium hypochlorite solution for five min, and then were dried indoors under shade and with aeration for $24 \mathrm{~h}$ at ambient temperature $\left(\mathrm{ca} .25^{\circ} \mathrm{C}\right)$. The morphological variables of the seeds measured were length, width, thickness, and mass, using a Somet digital calibrator and a Mettler Toledo AL 204 analytic scale. We counted the total number and determined the mass of seeds from each fruit. During the measurements, seed moisture content was estimated according to the ISTA protocol (1999). Approximately one-third of the seeds from each fruit were randomly selected and measured. Morphological variables were measured in a total of 1400 seeds.

Seed moisture content: Eighteen replications of 14 recently extracted seeds $(n=252)$ randomly selected from 20 ripe fruits were used. Seed moisture content was measured on a fresh weight basis using the constant hightemperature method (i.e., $130^{\circ} \mathrm{C}$ for one hour) with $15 \mathrm{~min}$ pre-drying of ground seeds at $70^{\circ} \mathrm{C}$ (ISTA 1999). A Krups model F203 electric mill, a Mettler Toledo AL 204 analytic scale, and a Thomas Scientific precision oven model TSOV2G were used.

Primary dormancy: The germination tests were conducted with four replications of 50 recently extracted seeds $(n=200)$, randomly selected from 30 ripe fruits. These seeds were submitted to dormancy breaking treatments: (1) Intact seeds pre-treated with distilled water for $24 \mathrm{~h}$ (wet control); (2) Seeds mechanically scarified with a scalpel; (3) Intact seeds (dry control).

After treatments, the seeds were placed in Petri dishes of $90 \mathrm{~mm}$ size with two layers of wet paper to germinate in a Kryoven incubator (irradiance $142.7 \mu \mathrm{mol} / \mathrm{m}^{2} . \mathrm{s}$ ) at constant temperature $\left(31^{\circ} \mathrm{C}\right)$ and a $12 / 12 \mathrm{~h}$ photoperiod. The test lasted 23 days. Germination was assessed every $48 \mathrm{~h}$ from the seventh day. Petri dishes of $90 \mathrm{~mm}$ size were used for this and all germination tests.

Germination dynamics and determination of the ecological group: To measure the response of seeds to their natural environmental conditions, the experimental conditions of temperature were established according to climatic data (mean-minimum/mean-maximum annual; mean/mean-maximum annual) reported for Buenaventura from 1961 to 1990 (IDEAM 2001). The day/night temperature regimes used $\left(20 / 30\right.$ vs. $\left.25 / 30^{\circ} \mathrm{C}\right)$ had different amplitudes $\left(10\right.$ vs. $\left.5^{\circ} \mathrm{C}\right)$, which correspond to forest clearings and understory, respectively. The experimental conditions of light corresponded to buried seeds (continuous darkness), open areas (12/12h photoperiod), small forest gaps or seeds under litter (15min lighting with far-red enriched light), sun flecks (15min lighting with red enriched light), and saturation of red light (lighting for 20.5h with red light).

A factorial experiment $(2 \times 5)$ was conducted with two day/night temperature regimes $\left(20 / 30\right.$ and $\left.25 / 30^{\circ} \mathrm{C}\right)$ with $16 \mathrm{~h}$ for the lower temperature and $8 \mathrm{~h}$ for the higher temperature, combined with five light treatments: (1) continuous darkness, (2) 12/12h photoperiod, (3) 15min lighting with far-red enriched light (730nm), (4) $15 \mathrm{~min}$ of lighting with red enriched light $(660 \mathrm{~nm})$ and (5) lighting for $20.5 \mathrm{~h}$ with red light. The seeds were imbibed in darkness in water for $15 \mathrm{~h}$ before the light treatments were applied, except for seeds of the $12 / 12 \mathrm{~h}$ photoperiod treatment, which were imbibed in the presence of light.

The far-red lighting was obtained by filtering the light produced by two incandescent $60 \mathrm{~W}$ bulbs (Osram perla) through two layers of Lee 26 filter and one layer of Lee 120 filter (Benvenuti et al. 2001). The red light was generated by two $20 \mathrm{~W}$ white fluorescent light tubes (Sylvania F20T12/D). Total darkness was 
achieved by storing the Petri dishes in double high-density black polypropylene bags.

To describe the germination behavior (distribution of germination in time) and understand how temperature fluctuation affects this behavior, we used seeds treated to $12 / 12 \mathrm{~h}$ photoperiod only at alternate temperatures $20 / 30$ and $25 / 30^{\circ} \mathrm{C}$.

The germination test had four replications of 75 seeds $(n=300)$ randomly selected extracted from 40 ripe fruits. The 12/12h photoperiod treatment was checked every $48 \mathrm{~h}$ from the seventh day until 31 days after the beginning of the test. For the other treatments there was only one revision after 32 days.

Behavior of seeds in storage: Seed behavior was determined by following the Hong \& Ellis (1996) protocol. A factorial $(3 \times 3 \times 2)$ experiment was conducted with three seed moisture contents (40.3, 10.6 and 5.9\%), three temperatures $\left(-20,5\right.$ and $\left.28^{\circ} \mathrm{C}\right)$, and two storage conditions (initial or no storage: zero month, and final storage: 1 month). The seeds were stored in vacuum sealed aluminum bags. The seeds were obtained from six ripe fruits and divided into two subgroups, one to determine seed moisture content and another to determine viability. Viability was measured by a germination test with four replications of 25 seeds each $(n=100)$, at alternate temperatures of $25 / 30^{\circ} \mathrm{C}$ and a $12 / 12 \mathrm{~h}$ photoperiod, which was the optimal condition found in the germination protocol.

Analysis of physiological variables: The emergence of the radicle was the criterion of germination. Germination percentages were transformed with the arc-sine function to stabilize the variances of the observations (Kuehl 2001). The mean germination time was calculated as the mean time to achieve maximum germination of a seed lot. Meanwhile, mean germination rate was calculated as the number of seeds germinated per unit of time (Ranal \& Santana 2006).

The synchrony of germination was determined by the $\mathrm{Z}$ index, which measures the synchrony of germination of a seed with another seed included in the same repetition of a treatment. $\mathrm{Z}$ varies between zero and one; it is one when the seeds germinate at the same time and zero when at least two seeds can germinate at distinct times (Ranal \& Santana 2006).

Depending on the behaviour of the data regarding normality and variance, we applied parametric tests for comparison of measurements (ANOVA, Tukey, Student's $t$-test and Dunnett) or non-parametric tests (Mann-Whitney). Data were analyzed with the Minitab Statistical Software program version 16. Differences were considered significant at $\alpha=0.05$.

\section{RESULTS}

Reproductive phenology and geographic distribution: According to the herbaria consulted, which have A. patinoi specimens collected between 1944 and 2008, this species is distributed along the American Tropical rainforest (sensu Primack \& Corlett 2005) from Costa Rica to Northern Ecuador, crossing the Chocó biogeographic region and reappearing in the Colombian Amazon, separated from the Chocó biogeographic by the Andean Mountains (Fig. 1). In 90\% of the records, this species was registered between 0 and $330 \mathrm{~m}$, although there were records up to $990 \mathrm{~m}$. Ripe fruits were found year round, but the herbaria records of ripe fruits were greater during January-February and September, which agrees with the observations made in Guaimía, Buenaventura, where fruiting had two peaks.

Seed morphometrics: The seeds collected in Guaimía, Buenaventura, measured $8.8 \pm 1 \mathrm{~mm}$ length; $6.3 \pm 0.8 \mathrm{~mm}$ width; $3.6 \pm 0.6 \mathrm{~mm}$ thick; and a mass $0.13 \pm 0.03 \mathrm{~g}$. Size and mass of seeds were relatively constant in $A$. patinoi, with low variation coefficients within and among fruits. However, these features varied slightly according to the variation of fruit mass. Thus, the linear regression of the relationship between fruit mass and seed length, and between fruit mass and seed mass were very close to zero (Fig. 2). The first relationship was substantially 


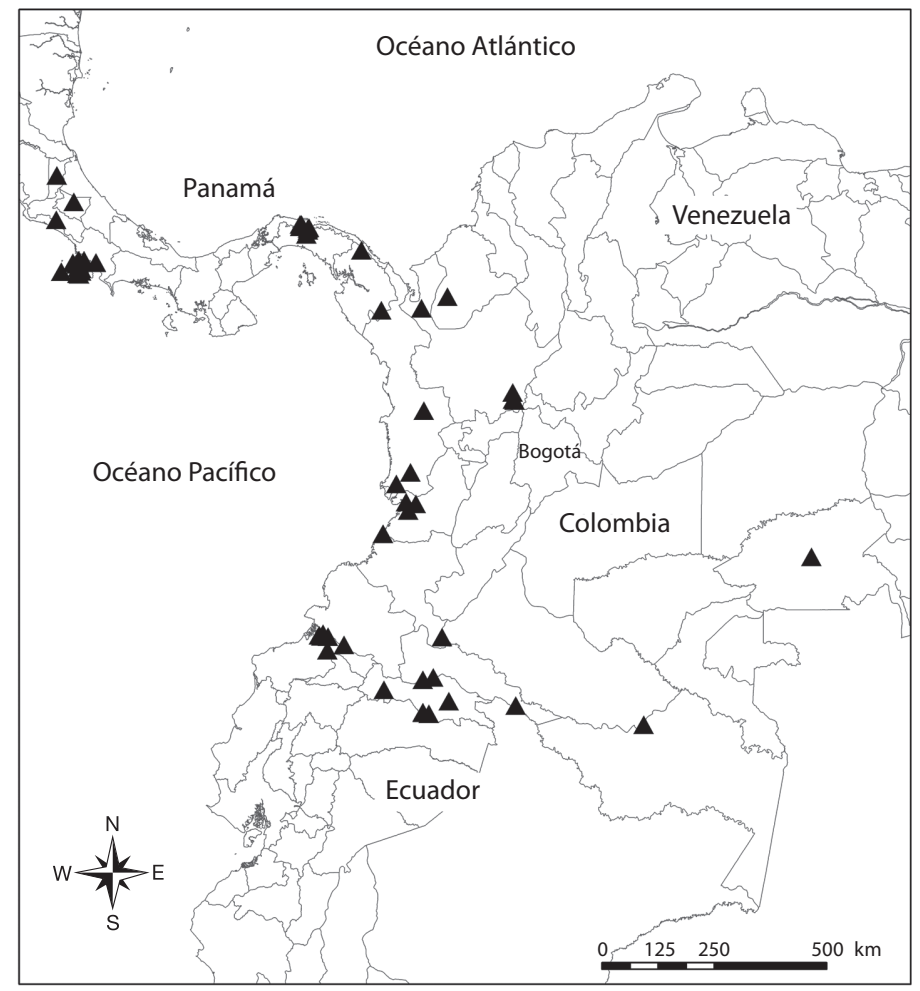

Fig. 1. Geographic distribution of A. patinoi according to historical records from herbaria collected between 1944 and 2008 , data layers based on Jonnes \& Bell (1997).

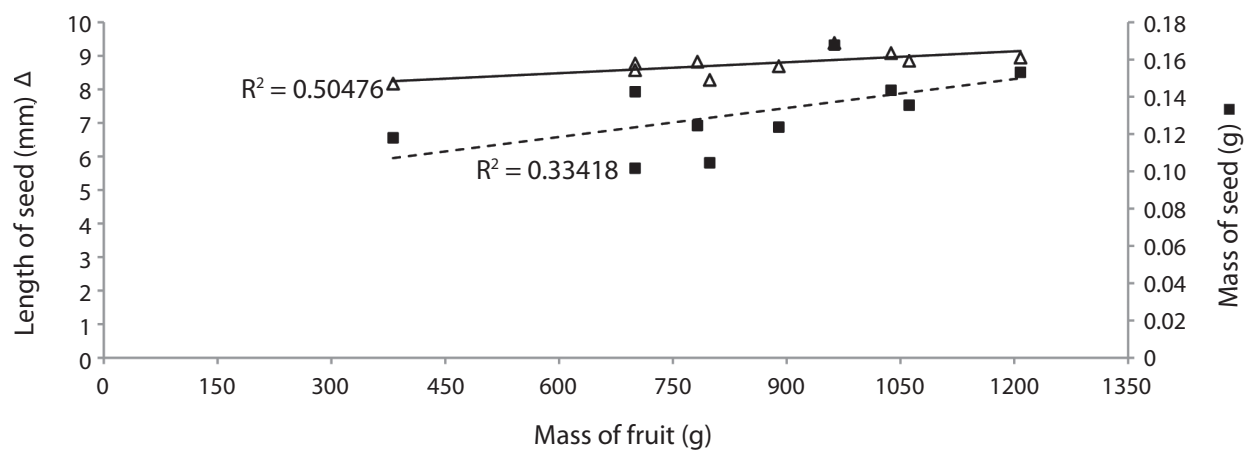

Fig. 2. Relationship between fruit mass and length and mass of the $A$. patinoi seeds. Seed length $=7.83+0.00109 x$ fruit mass (continuous line); seed mass $=0.0874+0.000052 x$; fruit mass (dashed line) $(\mathrm{n}=10$ fruits).

linear (sensu Davis 1971) and statistically significant ( $\mathrm{p}=0.021$ ), while the second one was moderately linear (sensu Davis 1971) and was not statistically significant $(\mathrm{p}=0.08)$ for the 10 fruits used.
The size and mass of the seeds of $A$. patinoi varied slightly within and among fruits, while seed number was highly variable and increased as fruit mass increased. The relationship between fruit mass and the number of 
seeds was positive, substantially linear (sensu Davis 1971), and statistically significant $(p=0.012)$ (Fig. 3).

Seed moisture content: $A$. patinoi seeds were released from the mother plant with high seed moisture content $(44.3 \pm 0.8 \%)$. In consequence, seeds presented continuous metabolism characteristic of recalcitrant species; these traits are typical of non-pioneer seeds of tropical rain forest (Hong \& Ellis 1996, Baskin \& Baskin1998).

Dormancy: The germination of recently harvested seeds was high $(97 \%)$ and was not affected by scarification (ANOVA, $\mathrm{p}=0.09$ ). The mean germination time of unscarified seeds was low (13.4d) (Dunnett, $\mathrm{p}<0.001$ ) and less than that of scarified seeds $(>14.2 d)$. Therefore, this species does not exhibit primary dormancy (sensu Baskin \& Baskin 1998).

Determination of the ecological group and germination dynamics: The seed germination under both alternating temperature regimes (20/30 vs. $25 / 30)$ and under all lighting conditions, including continuous darkness, was very high $(96.7-99.0 \%)$. Further, there was no difference in percentage germination among treatments with respect to quality of light (ANOVA, $\mathrm{p}=0.773$ ). Nor was there an interaction between lighting condition and temperature (Two way ANOVA, $p=0.609$ ). This means that $A$. patinoi behaves as an typical non-pioneer species.

On the other hand, temperature did affect germination (ANOVA, $\mathrm{p}=0.016$ ); the percentage germination of seeds incubated at $25 / 30^{\circ} \mathrm{C}$ was greater than those incubated at $20 / 30^{\circ} \mathrm{C}$. Mean germination time was less at $25 / 30^{\circ} \mathrm{C}$ than at $20 / 30^{\circ} \mathrm{C}(13.1 \mathrm{~d}$ or $14.6 \mathrm{~d}$, respectively; Student's $t$-test, $\mathrm{p}<0.001)$. Germination rate was greater for seeds incubated at $25 / 30^{\circ} \mathrm{C}$ than $20 / 30^{\circ} \mathrm{C}(0.08$ or 0.07 seeds $/ \mathrm{d}$, respectively, Student's $t$-test, $\mathrm{p}<0.002)$. The synchrony index of germination was not affected by temperature regime $(\mathrm{p}=0.773)$.

The pattern of germination distribution over time (Fig. 4) allows us to understand the low synchrony of germination under both temperature regimes, since seeds did not germinate at the same time. Moreover, seeds had an intermittent germination at both temperatures.

The seeds began to germinate on day seven and ended on day 25th. Germination occurred intermittently with two pulses of germination, on days 11 th and 16th, one of rapid germination and one of late germination. When seeds were incubated at $20 / 30^{\circ} \mathrm{C}$, the higher proportion of germination was on day 16 th, while at $25 / 30^{\circ} \mathrm{C}$ the major pulse of germination occurred on day 11 th.

Behavior of seeds in storage: $A$. patinoi seeds were sensitive to desiccation and had recalcitrant storage behavior. When seed

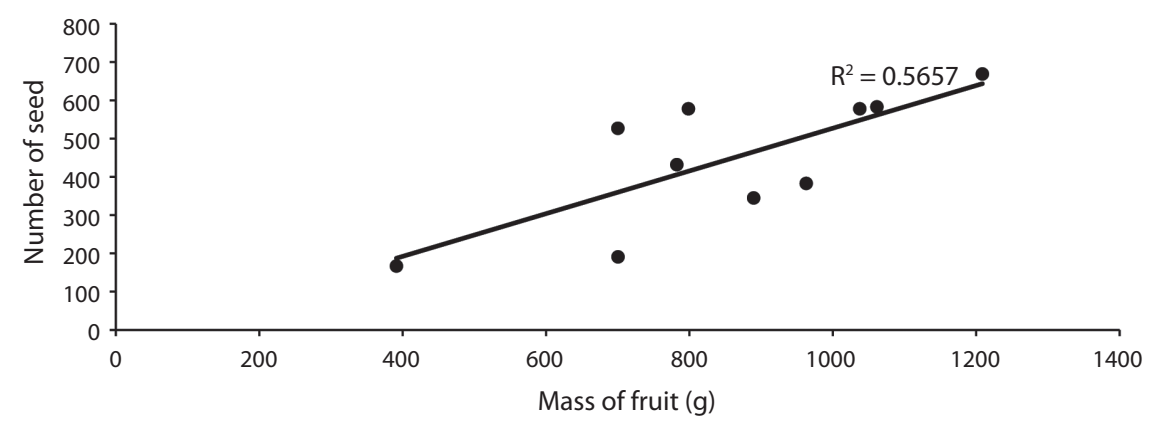

Fig. 3. Relationship between fruit mass and number of $A$. patinoi seeds. Number of seeds $=401.9+1.014 \mathrm{x}$ fruit mass ( $\mathrm{n}=10$ fruits). 




Fig. 4. Pattern of the germination distribution over time of $A$. patinoi seeds at two alternate temperatures and $12 / 12 \mathrm{~h}$ photoperiod. A) Cumulative germination \%. B) Germination distribution over time.

moisture content was high $(40.3 \%)$, the viability of the seeds was high $(98.8 \%)$, but when seed moisture content was below or equal to $11 \%$, the viability of seeds was drastically reduced and all the seeds died. When seeds were stored at low temperatures $\left(5^{\circ} \mathrm{C}\right)$ for one month and seed moisture content was high (40.3\%), viability was reduced, and $18 \%$ of the seeds died. In contrast, for seeds with high seed moisture content $(40.3 \%)$ and stored at extremely low temperatures $\left(-20^{\circ} \mathrm{C}\right)$ for one month the viability was lost entirely.

\section{DISCUSSION}

Size and mass of seeds are relatively constant in the population of $A$. patinoi studied with slight variation within a fruit and between fruits of different mass. According to Baker (1972) and Foster \& Janson (1985), each vegetation community has an optimal size of seeds that corresponds to the most frequent size. However, phylogenetic, ontological, habitat, and ecologic characteristics influence the size of the seeds, with a range of sizes tending to a most frequent value. A. patino $i$ seeds are within the range of size and mass of the tree species of mature tropical rainforest ( $\mathrm{Ng} \mathrm{1978,} \mathrm{Foster}$ \& Janson1985).

A. patinoi seeds are released from the mother plant with high moisture content ( $c a$. $44 \%$ ), continuous metabolism, and have recalcitrant behavior. Therefore, A. patinoi would be restricted to constantly humid locations, where its seeds are protected from desiccation by a thick layer of leaf litter or by a dense canopy. The high seed moisture content and continuous metabolism favor rapid germination, given that the seeds are released ready to germinate.

Percent germination is high $(>96 \%)$ and does not differ under the light conditions tested, nor do temperature and light interact to affect germination. That is, seeds germinate equally well in light or darkness, and they germinate at high percentages under conditions of alternate temperatures with an amplitude of 5 or $10^{\circ} \mathrm{C}$. Therefore, the seeds can germinate under conditions of dense canopies and thick layers of leaf litter (low red/far-red ratio and low temperature fluctuation) or buried (darkness and low 
temperature fluctuation) in the tropical rainforest. This germination behaviour makes $A$. patinoi a typical member of the ecological group "non-pioneer species" in the sense of Swaine \& Whitmore (1988), and the requirements of the seeds to germinate are easily fulfilled under the specific conditions in the mature tropical rainforest, favoring rapid germination.

The low germination synchrony under both temperature regimes is caused by intermittent germination, and the proportion of seeds germinating close to each peak differs with temperature. Thus, when the seeds are incubated at $25 / 30^{\circ} \mathrm{C}$, the proportion of seeds germinating around day 11 th is greater than the proportion germinating around day 16 th. When they are incubated at $20 / 30^{\circ} \mathrm{C}$ the proportions were reversed. Therefore, seeds germinate with higher percentage, faster and at a greater rate at the alternate temperature of $25 / 30^{\circ} \mathrm{C}$, favored by the lower amplitude $\left(5^{\circ} \mathrm{C}\right)$ or the closeness to the optimal temperature of germination (mean $26.6^{\circ} \mathrm{C}$ ). This temperature fluctuation is characteristic of soils of forests with dense vegetation cover, indicating that $A$. patinoi germinates more efficiently in shady forests than in clearings and forest gaps, confirming that the species is a non-pioneer.

The physiological characteristics of $A$. patinoi seeds are typical of non-pioneer species of the tropical rainforest. Consistent with this, more than $60 \%$ of the species from the tropical rainforest do not have primary dormancy (Baskin \& Baskin 1998), and non-pioneer species from rainforests have recalcitrant seeds regardless of the geographic location ( $\mathrm{Ng} 1978$, Hong \& Ellis 1996, Baskin \& Baskin 1998).

The rapid germination rate (sensu $\mathrm{Ng}$ 1978 ) is the establishment strategy of $A$. pati$n o i$, and this behaviour is favored by seed physiological traits such as: (1) lack of primary dormancy; (2) ability to germinate over a range of light conditions; and (3) recalcitrant behavior, seeds with high moisture content, and continuous metabolism. However, ability to germinate rapidly depends on seeds being exposed to the high temperatures characteristic of the shady tropical rainforest floor. This establishment strategy is the most common in species of trees from the mature tropical rainforest, under which all the seeds germinate in a short period of time, presenting high density of seedlings, not forming banks of persistent seeds and not presenting primary dormancy, along with low germination requirements (Ng 1978, Vázquez-Yánez \& Orozco-Segovia 1993, Baskin \& Baskin 1998).

In the mature tropical rainforest, seeds are commonly exposed to constantly high temperature and humidity and low light intensities that favor the proliferation of pathogenic microorganisms. Furthermore, in these locations seed predation is so high that nearly half the seeds produced by over $90 \%$ of all the tree species from the tropical forest die because of fungi and predators ( $\mathrm{Ng} \mathrm{1978,} \mathrm{Vázques-Yanes} \mathrm{\&}$ Orozco-Segovia 1993, Dalling 2002, Mantilla 2004). These conditions favor traits that allow seeds to survive pathogen attacks but in detriment of the ability to expand to new territories (Ng 1978, Augspurger 1984, Vázques-Yanes \& Orozco-Segovia 1993).

One trait of seed survival is rapid germination, as it diminishes seed death by pathogenesis and predation because it reduces the time spent as a seed, given that the nutritional reservoir is greater for seeds than for seedlings. Besides, seedlings are usually less susceptible to parasitism and depredation, especially when the seedlings grow slowly because their cell walls thicken rapidly (Augspurger 1984). In addition, rapid germination increases the concentration of seedlings producing a high offer that satiates the predators or leads them towards the higher density of seedlings, generally near the mother plant, allowing seeds to survive and establish themselves at the limit of the dispersal area ( $\mathrm{Ng} \mathrm{1978).}$

In conclusion, the seed physiological traits (i.e., rapid germination rate, low germination requirements, non-primary dormancy, and recalcitrant behaviour) of $A$. patinoi, as well as seed size and mass, suggest that this species is well adapted to its mature tropical rain forest habitat. In addition, this species is a typical member of the ecological group of 
"non-pioneer species" in the sense of Swaine \& Whitmore (1988).

\section{ACKNOWLEDGMENTS}

We wish to thank the community of Guaimía, Philip A. Silverstone Sopkin, Director of the CUVC herbarium, Yan A. Ramos, director of the CHOCO herbarium, Mercedes Andrade for her statistical advice, John Miles for reading the manuscript, Jorge Rubiano for the mapping, the Group of Research on Quantum Optics at the Universidad del Valle for the technical support, Manuel Giraldo G., Aleyda Acosta, and the personnel from the CUVC herbarium for their help and support, and COLCIENCIAS and the Office of the Governor of Valle del Cauca for funding this research.

\section{RESUMEN}

La germinación y morfometría de las semillas de $\mathrm{Ali}$ bertia patinoi se describen y se relacionan con el hábitat de la especie, el Bosque Pluvial Tropical Americano. Se midió la longitud, ancho, grosor, peso y contenido de humedad de las semillas. Se realizaron pruebas de latencia, imbibición y dinámica de la germinación con diferentes condiciones de luz y temperatura específicas de claros y de sotobosque cubierto por un dosel denso. Además, se estableció el comportamiento de almacenamiento de las semillas. El tamaño y peso de las semillas no difieren dentro ni entre frutos. Las semillas recién cosechadas no tienen latencia primaria, presentan alto contenido de humedad (ca. 44\%), metabolismo continuo y son recalcitrantes. La germinación tuvo porcentajes altos y en condiciones de luz y temperatura específicas de bosque con follaje denso, y ni la luz enriquecida con rojo lejano ni la oscuridad inhibieron la germinación. Se concluye que la germinación rápida podría ser la estrategia de establecimiento de esta especie. Además, los rasgos fisiológicos, el tamaño y peso de las semillas, sugieren que $A$. patinoi está adaptada a las condiciones del bosque lluvioso tropical maduro y se comporta como una especie que no es pionera.

Palabras clave: luz rojo-lejano, bosque pluvial tropical maduro, especie no pionera, semillas sin latencia, estrategia de germinación rápida, semilla recalcitrante.

\section{REFERENCES}

Augspurger, C.K. 1984. Light requirements of Neotropical tree seedlings: a comparative study of growth and survival. J. Trop. Ecol. 72: 777-795.
Baker, H.G. 1972. Seed mass in relation to environmental conditions in California. Ecology 53: 997-1010.

Baskin, C.C. \& J.M. Baskin. 1998. Seeds. Ecology, biogeography, and evolution of dormancy and germination. San Diego Academic, San Diego, USA.

Benvenuti, S., M. Macchia \& S. Miele. 2001. Light, temperature and burial depth effects on Rumex obtusifolius seed germination. Weed Res. 41: 177-186.

Dalling, J. 2002. Ecología de semillas, p. 345-376 In M. Guariguata \& G. Kattan (eds.). Ecología y conservación de bosques Neotropicales. Ediciones LUR, Costa Rica.

Davis, J.A. 1971. Elementary survey analysis. PrenticeHall, Englewood, New York, USA.

Espinal, L.S. \& E. Montenegro. 1963. Formaciones vegetales de Colombia. Memoria explicativa sobre el mapa ecológico. Instituto Geográfico Agustín Codazzi, Bogotá, Colombia.

Foster, S.A. \& C.H. Janson. 1985. The relationship between seed size and establishment conditions in tropical woody plants. Ecology 66: 773-780.

Hong, T.D. \& R.H. Ellis. 1996. A protocol to determine seed storage behavior. Technical Bulletin N 1. International Plant Genetic Resources Institute, Italy.

Instituto de Hidrología, Meteorología y Estudios Ambientales de Colombia (IDEAM). 2001. Atlas climatológico colombiano, Colombia. (Downloaded: April 10, 2008, http://www.ideam.gov.co/atlas/mclima.htm).

International Seed Testing Association (ISTA). 1999. Rules. Proceedings of the International Seed Testing Association. Seed Sci. Technol. 27. Supplement.

Jonnes, P.G. \& W.C. Bell. 1997. Cobertura de América Latina. División Administrativa. Versión 1.1 Abril 1997 Formato Digital. CIAT, Cali, Colombia.

Kuehl, R. 2001. Diseño de Experimentos. Thomson-Learning, México D.F., México.

Mantilla, A. 2004. Ecofisiología de la germinación de semillas, p. 901-922. In M.J. Reigosa, N. Pedrol \& S.A. Sanchez-Moreira (eds.). La ecofisiología vegetal: una ciencia de síntesis. Thomson, España.

Martinez-Ramos, M. \& A. Soto-Castro. 1993. Seed rain and advanced regeneration in a tropical rain forest, p. 299-318. In T.H. Flemming \& A. Estrada (eds.). Frugivory and seed dispersal: Ecological and Evolutionary Aspects. Kluwer Academic, Belgium.

Mendoza, H., B. Ramírez \& L.C. Jiménez. 2004. Rubiaceae de Colombia. Guía ilustrada de géneros. Instituto de Investigación de Recursos Biológicos Alexander von Humboldt, Bogotá, Colombia.

Ng, F.S.P. 1978. Strategies of establishment in Malayan forest trees, p. 129-162. In P.B. Tomlinson \& M.H. Zimmerman (eds.). Tropical trees as living systems. Cambridge University, Cambridge, United Kingdom. 
Orozco-Segovia, A., C. Sanchez-Coronado \& C. VasquezYanes. 1993. Light environment and phytochromecontrolled germination in Piper auritum. Funct. Ecol. 7: 585-590.

Paine, C.E.T. \& H. Beck. 2007. Seed predation by neotropical rain forest mammals increases diversity in seedling recruitment. Ecology 88: 3076-3087.

Patiño, V.M. 2002. Historia y dispersión de los frutales nativos del neotrópico. Centro Internacional de Agricultura Tropical, Cali, Colombia.

Paz, H., S.J. Mazer \& M. Martinez-Ramos. 1999. Seed mass, seedling emergence, and environmental factors in seven rain forest Psychotria (Rubiaceae). Ecology 80: 1594-1606.

Poorter, L. \& S.A. Rose. 2005. Light-dependent changes in the relationship between seed mass and seedling traits: a meta-analysis for rain forest tree species. Oecologia 142: 378-387.

Primack, R. \& R. Corlett. 2005. Tropical rain forests: an ecological and biogeographical comparison. Blackwell Science, Oxford, United Kingdom.
Ranal, M.A. \& D.G. Santana. 2006. How and why to measure the germination process? Rev. Bras. Botânica 29: 1-11.

Souza, R.P. \& I.F.M. Valio. 2001. Seed size, seed germination, and seedling survival of Brazilian tropical tree species differing in successional status. Biotropica 33: 447-457.

Svenning, J.C. 2000. Small canopy gaps influence plant distributions in the rain forest understory. Biotropica 32: 252-261.

Svenning, J.C. \& J .Wright. 2005. Seed limitation in a Panamanian forest. J. Ecol. 93: 853-862.

Swaine, M.D. \& T.C. Whitmore. 1988. On the definition of ecological species groups in Tropical Rain forest. Vegetatio 75: 81-86.

Thiers, B. 2012. Index Herbariorum: A global directory of public herbaria and associated staff. New York Botanical Garden's Virtual Herbarium. (Downloaded: June 24, 2012, http://sweetgum.nybg.org/ih/).

Vazquez-Yanes, C. \& A. Orozco-Segovia. 1993. Patterns of seed longevity and germination in the tropical rainforest. Ann. Rev. Ecol. Syst. 24: 69-87. 